\title{
Akhenaten, a unique pharaoh
}

To the Editor: Retief and Cilliers ${ }^{1}$ suggest an interesting new theory about Akhenaten's physical appearance, but omitted to refer to previously suggested differential diagnoses: for example, schistosomiasis, ${ }^{2}$ myotonic dystrophy, ${ }^{3}$ elephantiasis ${ }^{4}$ and AntleyBixler syndrome have also been suggested. ${ }^{5}$ More recently, we proposed homocystinuria as a possible cause. ${ }^{6}$ Since Kallman's syndrome is a hereditary disease, it is important to see how this diagnosis fits into Akhenaten's family tree. The fact that Akhenaten's wife, Nefertiti, and their children were similarly depicted implies that they suffered from the same disease. Akhenaten's parents, Amenhotep III and Tiye, were most probably healthy. The genetics of Kallman syndrome are still not fully understood. ${ }^{7}$ However, two of the best-described forms of Kallman syndrome are inherited autosomal dominant and X-linked disorder. ${ }^{7}$ An obvious problem with this diagnosis is the healthy father, although it cannot be fully rejected because the phenotype of these patients varies from partial to complete. However, as we explained in our article, an autosomal recessive disease, such as homocystinuria, is the most probable explanation. Although, admittedly, all proposed diagnoses have their advantages and drawbacks, it is important to note that all of them are made under one assumption: that art from the Amarna period was realistic, i.e. that this was not just a form of artistic expression creating a distance from traditional Egyptian art. The authors do not cite an investigation by Hawass et al., in which it was suggested that a mummy found in KV55 was actually Akhenaten; ${ }^{8,9}$ they also suggest that the depictions of Akhenaten exaggerate his actual appearance. However, the definitive confirmation of both the identity of the KV55 mummy and a possible diagnosis can be made only by DNA analysis. Unfortunately, the method for DNA sampling is the subject of heavy criticism, and the results do not appear to be totally trustworthy. ${ }^{10}$

\section{Tomislav Kelava}

Department of Physiology

University of Zagreb Medical School

Croatia

\section{Mislav Cavka}

Department of Diagnostic and Interventional Radiology

Dubrava University Hospital

Zagreb

mislav.cavka@yahoo.com

\footnotetext{
Retief FP, Cilliers L. Akhenaten, a unique pharoh. S Afr Med J 2011;101:628-630.

2. Ghalioungui P. Health and Healing in Ancient Egypt. Cairo: Centre of Documentation and Studies on Ancient Egypt, 1965.

on Ancient Egypt, 1965.

3. Cattaino G, Vicario L. Myotonic dystrophy in Ancient Egypt. Eur Neurol 1999;41:59.
4. Velikovsky I. Oedipus and Akhnaton, Myth and History. New York: Doubleday \& Company Inc, 1960.

4. Velikovsky I. Oedipus and Akhnaton, Myth and History. New York: Doubleday \& Company Inc, 1960.
5. Braverman IM, Redford DB, Mackowiak PA. Akhenaten and the strange physiques of Egypt's 18th Braverman IM, Redford DB, Mackowiak PA.
dynasty. Ann Intern Med 2009;150:556-560.

dynasty. Ann Intern Med 2009;150:556-560.
6. Cavka M, Kelava T, Cavka V, Busic Z, Olujic B, Brkljacic B. Homocystinuria, a possible solution of the 6. Cavka M, Kelava T, Cavka V, Busic Z, Olujic B, Brkljacic B. Ho
Akhenaten’s mystery. Coll Antropol 2010;34 supp1:255-258.

7. Sarfati J, Dodé C, Young J. Kallmann syndrome caused by mutations in the PROK2 and PROKR2 genes: pathophysiology and genotype-phenotype correlations. Front Horm Res 2010;39:121-132.

8. Hawass Z, Gad YZ, Ismail S, et al. Ancestry and pathology in King Tutankhamun's family. JAMA 2010;303:638-647.

9. Eshraghian A. Akhenaten's mystery remains. S Afr Med J 2011:101:780.

10. Marchant J. Ancient DNA: Curse of the Pharaoh's DNA. Nature 2011:472:404-406.
} 